\title{
An Analysis Of The United Arab Emirates Banking Sector
}

M. Anaam Hashmi, (E-mail: m.hashmi@mnsu.edu), Minnesota State University

\begin{abstract}
The UAE has a fragmented banking sector. A total of 46 domestic and foreign banks are operating in the UAE. The banking sector is somewhat protected; however, foreign banks are becoming increasingly active in the economy. The banking sector is gearing up to meet global challenges by adopting Basel II banking standards. The big five banks dominate the banking sector and all of the large ten banks are financially sound. The banking sector is well managed by the UAE Central Bank which is a positive factor for the country's growth and globalization efforts because the UAE banking sector has grown drastically and is gearing up for global competition.
\end{abstract}

\section{INTRODUCTION}

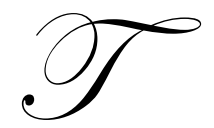

he United Arab Emirates (UAE) is a federation of seven small American Gulf emirates: Abu Dhabi, Dubai, Sharjah, Ajman, Umm Al Qaiwain, Ras Al Khaimah and Fujairah. UAE is a member of the Gulf Cooperation Council (GCC), and the country is traditionally an oil and gas exporting nation. Currenlty, each of the emirates has a relatively stable economic and political system, and the country has an ambition to emerge as a financial and service sector leader in the Middle East.

UAE has proven crude oil reserves of around 98 billion barrels (or 10\% of the world's reserves). The oil wealth is concentrated in Abu Dhabi, which contributes approximately $90 \%$ of the total oil production of the country. UAE also boasts substantial reserves of natural gas, accounting for $4 \%$ of the world's reserves. The bulk of gas reserves (over 90\%) are located in Abu Dhabi as well. The emirate of Dubai has also become an important financial center in the UAE because of its significant financial and services industries. Abu Dhabi and Dubai have emerged as the two most important emirates of the UAE.

\section{UAE Banking Sector}

The purpose of this study is to analyze the banking sector of the UAE and study its readiness to be a part of the global financial system. As of 2005, the small UAE banking sector was served by 21 domestic and 25 foreign banks, thus the UAE banking sector is quite fragmented. Banks incorporated in Abu Dhabi and Dubai hold more than $90 \%$ of the total domestic assets, with this total being divided almost equally between Abu Dhabi and Dubai banks.

Market access for foreign banks was somewhat limited because they were not allowed to open more than eight branches throughout the modern banking operation (1980-2003). In 2003, however, laws were changed, and today banks are allowed to open more than eight branches but special permission is required. Foreign banks confronted no obstacles, however, when they wanted to open a representative office. At the end of 2004, there were thirty-six representative offices throughout the emirates. Thus, UAE has been well represented by a cross-section of foreign banks. A list of all domestic and foreign banks operating in the UAE is provided in Appendix 1 and a list of representative offices of foreign banks is provided in Appendix 2. (Central Bank of the UAE, 2006)

Federal Law 10, enacted in 1980, is the backbone of the conventional banking sector (excluding Islamic banks), and Federal Law 6 was promulgated in 1985 to legalize Islamic banking in the UAE. Islamic banking is still a small component of the UAE banking sector. According to Islamic banking laws, banks cannot charge a fixed interest 
rate on deposits or loans. Variable interest rates based on a profit / loss sharing model is the foundation of Islamic banking.

Under the Federal Law 10, the Central Bank of the UAE was also established, and it took over the responsibilities of the Currency Board. The bank's duties include advising the government on monetary and financial issues, issuing currency, maintaining gold and foreign currency reserves, and formulating a credit policy. All regulation and supervisory duties are under the direction of the Central Bank.

The UAE currency is pegged to the US dollar, which is why the central bank has a limited role to play in setting monetary policy and controlling interest rates; however, some monetary and credit controls are exercised through its sale and purchase of certificates of deposits. The central bank plays a role in formulating and monitoring credit policy, and in supervising the financial sector as well. All commercial banks incorporated in the UAE are licensed by the central bank, and therefore are subject to the central bank's requirements and regulations. In 1998, the central bank made it mandatory for all banks to use International Accounting Standards (IAS), and in early 1999, local banks were instructed to establish clear corporate structures. Furthermore, the UAE central bank requires banks to maintain a capital to risk-weighted assets ratio of at least $10 \%$ at all times. According to the Central Bank of UAE regulations, all banks must be majority owned by UAE nationals. They also have to be registered as "Shareholding Company" under the UAE Companies Law and must be registered with the Federal Ministry of Economy and Trade. (Central Bank of the UAE, 2005)

\section{LITERATURE REVIEW}

Rao (2002) studied 35 domestic and foreign banks operating in UAE for 1998 and 2000. He examined cost efficiency, scale and scope measure, and cost productivity growth rate. As a result of his research, Rao (2002) concluded that substantial cost inefficiencies and scope economies existed in UAE banks. In addition, he found that only small banks improved their scale economies while large banks maintained status quo. This finding reveals that the management teams of small banks were capable of managing their portfolio more efficiently than larger banks.

Duncan and Elliott (2002) empirically examined the relationship between service quality and financial performance among a representative cross-section of Australian banks and credit unions. They found that all financial performance measures are positively correlated with service quality scores. Al-Tamimi and Al-Amiri (2003) studied two major Islamic banks in UAE (Dubai Islamic Bank and Abu Dhabi Islamic Bank). These two banks dominate the Islamic banking sector, operating 21 branches throughout UAE (only five percent of conventional banks). They compared the service quality of these banks with well-established SERVQUAL standards. The study found that these two major banks have statistically significant perceived service quality. This finding is contrary to the belief that most of the domestic conventional and Islamic banks may have a service quality issue with customers. In order to compete with foreign banks, particularly when the banking sector opens up, UAE banks must focus on service quality. Most of the studies have indicated the existence of a positive relationship between service quality and profitability.

Prior studies have suggested that an efficient and growing banking sector is a predictor of the future economic conditions of a country. El-Kuwaiz (1995) and De Gregorio and Guidotti (1995) show that measures of banking development are strongly correlated with economic growth in broad cross-section countries. Countries with efficient and growing banking sectors tend to grow rapidly. Similarly, King and Levine (1993) have established a strong link between the financial progress of a country and banking industry's growth. Prior to these two studies, Goldsmith (1969) concluded, on the basis of data from 35 countries between 1860 and 1963, that "a rough parallelism can be observed between economics and financial development if periods of several decades are considered." According to these studies, a well functioning financial system is critical for sustained economic growth.

\section{RESEARCH METHODOLOGY}

This is an analytical and cross-sectional study of UAE banks that analyzes and compares the domestic and foreign banks' micro and macro characteristics. This study also discusses the readiness of domestic banks to meet global challenges. Secondary data sources are utilized for comparing individual banks and comparing the domestic / 
foreign banking sector in the UAE. The banks' financial reports, the website of the Central Bank of UAE, EFG Hermes's website, and other published sources are heavily used during the course of this study. All the data is either in millions of UAE dirham (AED) or millions of U.S. dollar (\$).

For an in depth analysis, eight large conventional domestic banks, two large domestic Islamic banks, and the top ten domestic banks are included in this study. The top banks are selected according to the 2004 shareholder's equity (first tier capital) as defined by the Bank of International Settlements (BIS). At times, two comparable conventional foreign banks' data is also included for comparison purposes. In addition, aggregate data for all domestic and foreign banks is used whenever available. However, comparable data was not always available before 2001 and after 2004, which is why the selected time period of this study is $2001-2004$.

\section{ANALYSES OF UAE BANKING SECTOR}

UAE banks, along with Saudi Arabian and Kuwaiti banks, have dominated the GCC and Middle Eastern banking sector. Because of the number of banks in the UAE, the country's banks are rated ninth, tenth, fourteenth, fifteenth, eighteenth, twenty-eighth, fortieth, forty-first, forty-eighth, and fifty-fifth among the top Middle East banks. This ranking is based on the tier-one shareholders equity as defined by Bank of International Settlement (BIS). A list of top ten conventional and Islamic banks with their rank among the top hundred Middle Eastern banks, capital, assets, profits, ROE and ROA are presented in Table 1. The most noticing observation is that all banks were profitable in 2004. The UAE Central Bank required banks to maintain a $10 \%$ capital / assets ratio and most of the banks exceeded the requirement. In fact, only three banks (NBAD, UNB, and CBD) had slightly lower capital / assets ratios, and even these banks were very close to the 10 percent mark. The research also reveals that ROE and ROA were much higher in conventional banks than Islamic banks. The highest ROE in 2004 was reported by the Union National Bank (20.3\%), while the highest ROA was reported by the Commercial Bank of Dubai (3.3\%). The top UAE bank based on capital was the Emirates Bank International, and the top UAE bank based on assets was the National Bank of Abu Dhabi.

Table 1

Financial Profile Of Top Ten Domestic Banks, (2004)

\begin{tabular}{|l|c|c|c|c|c|c|c|}
\hline \multicolumn{1}{|c|}{ UAE Banks } & $\begin{array}{c}\text { Mid- } \\
\text { East } \\
\text { Rank }\end{array}$ & $\begin{array}{c}\text { Capital } \\
\mathbf{( \$ \text { mil.) }}\end{array}$ & $\begin{array}{c}\text { Assets } \\
\mathbf{( \$ ~ m i l . )}\end{array}$ & $\begin{array}{c}\text { Capital } \\
\text { Asset } \\
(\%)\end{array}$ & $\begin{array}{c}\text { Profits } \\
\mathbf{( \$ ~ m i l . ) ~}\end{array}$ & $\begin{array}{c}\text { ROE } \\
(\%)\end{array}$ & $\begin{array}{c}\text { ROA } \\
(\%)\end{array}$ \\
\hline Emirates Bank International (EBI) & 9 & 1,585 & 10,371 & 15.3 & 281 & 17.7 & 2.7 \\
\hline National Bank of Dubai (NBD) & 10 & 1,482 & 10,972 & 13.5 & 253 & 17.1 & 2.3 \\
\hline National Bank of Abu Dhabi (NBAD) & 14 & 1,413 & 15,349 & 9.2 & 310 & 22 & 2.0 \\
\hline Abu Dhabi Commercial Bank (ADCB) & 15 & 1,352 & 10,461 & 13.0 & 218 & 16.1 & 2.1 \\
\hline Mashreq Bank (MASHREQ) & 18 & 1,244 & 8,699 & 14.3 & 226 & 18.1 & 2.6 \\
\hline Dubai Islamic Bank (DIB) & 28 & 814 & 8,342 & 9.7 & 126 & 15.4 & 1.5 \\
\hline Union National Bank (UNB) & 40 & 604 & 6,570 & 9.2 & 123 & 20.3 & 1.8 \\
\hline Commercial Bank of Dubai (CBD) & 41 & 564 & 2,880 & 19.5 & 96 & 17.0 & 3.3 \\
\hline First Gulf Bank (FGB) & 48 & 484 & 3,484 & 13.9 & 67 & 13.8 & 1.9 \\
\hline Abu Dhabi Islamic Bank (ADIB) & 55 & 410 & 3,457 & 11.8 & 33 & 8.0 & 0.9 \\
\hline
\end{tabular}

Source: Siddiqi (2005)

The involvement of UAE banks (domestic and foreign) in the local deposit and loan market is summarized in Table 2. The National Bank of Abu Dhabi (NBAD) has by far the most deposit and loan market share (about $13 \%$ ). The National Bank of Dubai (NBD) has the second most deposits and Emirates Bank International (EBI) has the second most loan issues. It is observed that only two foreign banks are included among the top ten banks based on deposit and loan market share. The two foreign banks (HSBC and Standard Chartered) have a much smaller share of the deposit and loan market. Among all the 46 banks operating in UAE, domestic banks dominated the deposit market share $(74 \%)$ and the loan market share (79\%) at the end of 2003. Most of the banks operating in UAE are very small, 
as the top five out of forty-six banks controlled $48 \%$ of the deposits and $48 \%$ of the loan market in 2003. (Central Bank of UAE, 2005)

Table 2

Deposit and Loan Market Share Of Top Ten Domestic/Foreign Banks (2003)
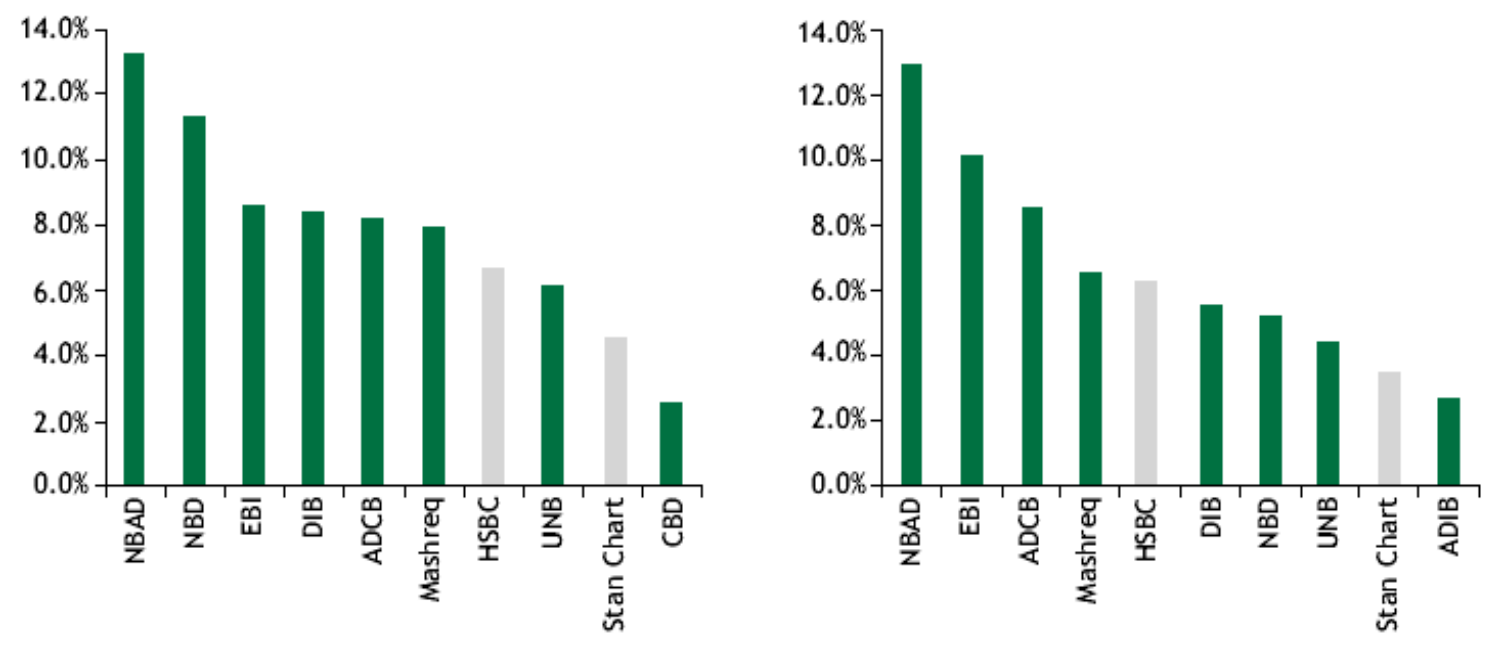

Source: Central Bank of the UAE, bank's financial statements

The banks in the UAE are not separated from non-banking commercial activities. Banks are allowed to participate in stock brokerage, real estate brokerage, securities market and other non-banking activities. Because stock and real estate brokerage incomes are volatile, banks cannot completely rely on them. Other sources of non-interest income (also called core non-interest income) are foreign exchange related incomes and commissions / fees. Foreign exchange transaction income has been less volatile over the years so banks have tried to increase the share of foreign exchange income.

\section{Retail Banking}

The UAE has a rapidly growing retail banking sector because of the country's increasing expatriate population. Domestic and foreign banks have made a large investment in low cost distribution channels such as internet banking and ATM networks. UAE banks are still focused on corporate customers because they are considered low risk and lucrative. As a result, business loans have been increasing at the expense of personal loans, but retail deposits are still significant as they provide capital to the banks. Also, loans to business and corporate customers lead to other lucrative business opportunities such as a letter of credit and a letter of guarantee issuance. That is why business loans are still preferred by UAE banks.

The UAE personal loan market is under penetrated compared to other GCC countries. In 2003, the personal loan ratio to GDP (penetration rate) was 7\% which is well below the penetration rate of Saudi Arabia (8 \%), Oman (15 $\%$ ), Bahrain (22\%) and Qatar (26\%). (EFG Hermes, 2004; Central Bank of UAE, 2004). The personal loan share of the major domestic banks is presented in Table 3. Data has been collected for 2001, 2002 and 2003. Abu Dhabi Commercial Bank (ADCB) is the market leader in the personal loan market with $25 \%$ of the market share in 2001 and about $18 \%$ of the market share in 2003. The other three banks each have a market share of between 10-12\% in 2003, thus the four banks control more than half the personal loan market. The reluctance by most of UAE banks to become heavily involved in the personal loan market can be explained by the absence of consumer credit reports and the lack of trust toward an expatriate workforce that has not had a long-term residency status. Expatriates cannot open a bank account or apply for any service without a guarantee letter from an employer and other personal guarantees. 
Table 3

Personal Loan Share Of The Domestic Banks

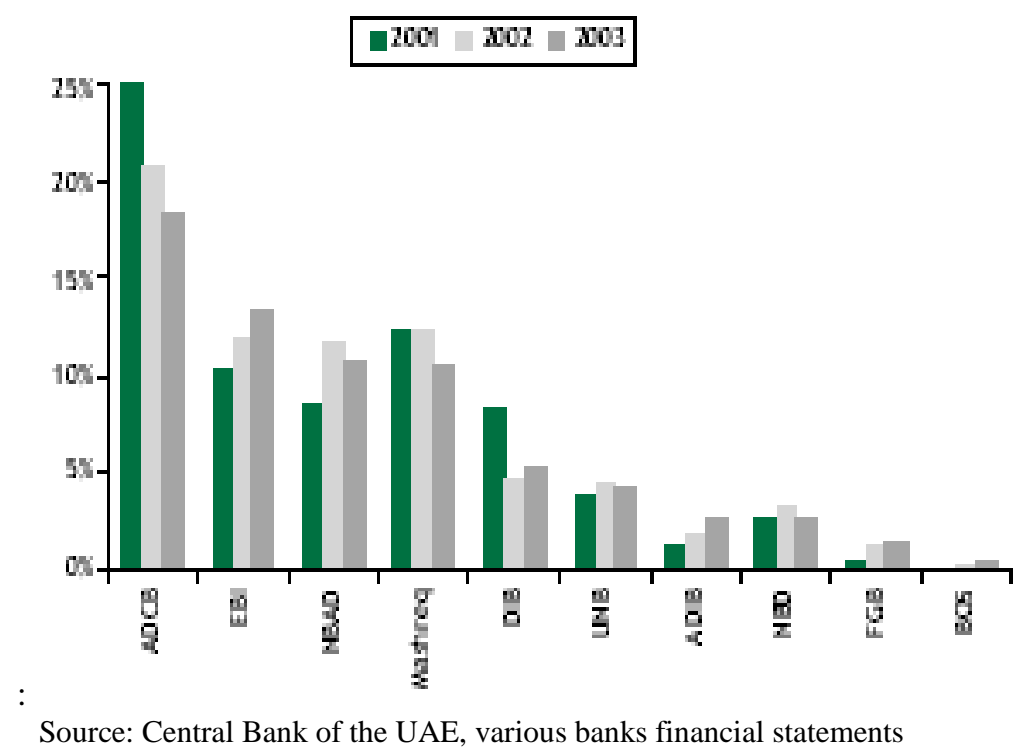

\section{Micro Comparison Of Domestic Banks}

As with other data analysis in this study, only large banks are selected for this cross sectional analysis. Banks are classified into conventional and Islamic banks, and further conventional banks are grouped into high growth, moderate growth, and slow growth categories. The growth criterion is based on the asset growth during the 33 months period (from the end of 2001 to September 2004). Computed data is summarized in Table 4.

The banks characterized by fast growth (57-140\% balance sheet growth) are also characterized by high earnings growth rates, high loan to deposit ratios (90-137\%), high market capitalization to deposit ratios (100-165\%), high historic earnings multiples (30-33x trailing twelve months earnings) and low dividend yields (0.6-0.9\%). The banks in the moderate growth category have balance sheet growth rates ranging from $28 \%$ to $54 \%$, moderate earnings growth rates, moderate loan to deposit ratios (80-104\%), moderate market capitalization to deposit ratios (51-102\%), moderate $\mathrm{P} / \mathrm{E}$ ratios (16-28x trailing twelve month earnings), and moderate dividend yields (1.8-2.2\%). The author has included the National Bank of Abu Dhabi (NBAD) in the moderate growth group despite an asset growth of 54\%, which is at the bottom end of the fast growing group. This is because its asset base was abnormally low at the end of 2001 after an outflow of deposits that year due to an interest rate competition that the bank was unwilling to engage in. The two banks in the slow growth category were going through structural changes during the selected period of the study.

Islamic banks as a group exhibit a mixture of the characteristics of both fast and moderate growth conventional banks: The two largest by market capitalization, Dubai Islamic Bank (DIB) and Abu Dhabi Islamic Bank (ADIB), are also the two most heavily traded among all domestic banks. Therefore, these two banks fit clearly into the fast growth group (growth of 77-83\%). Despite fast asset growth, these banks have very low loan to deposit ratios (63-81\%), indicating an easy ability to attract deposits and extremely conservative loan approval criteria. Financial valuations of domestic banks are mixed with the lowest market capitalization to deposit ratios in the universe (39$48 \%)$ and reasonable dividend yields (1.6-1.7). 
Table 4

Domestic Bank's Growth Comparison

\begin{tabular}{|l|c|c|c|c|c|c|}
\hline & $\begin{array}{c}\text { Mkt. Cap* } \\
\text { (AED mil) }\end{array}$ & $\begin{array}{c}\text { Trade Val. } \\
\text { (AED mil) }\end{array}$ & $\begin{array}{c}\text { Asset } \\
\text { Growth }\end{array}$ & $\begin{array}{c}\text { Loan } \\
\text { Growth }\end{array}$ & $\begin{array}{c}\text { Deposit } \\
\text { Growth }\end{array}$ & $\begin{array}{c}\text { Loan / } \\
\text { Deposit }\end{array}$ \\
\hline Fast Growth & & & & & & \\
\hline First Gulf Bank & 6,133 & 113 & $140 \%$ & $256 \%$ & $119 \%$ & $100 \%$ \\
\hline Emirates Bank & 26,749 & 47 & $57 \%$ & $91 \%$ & $46.3 \%$ & $137 \%$ \\
\hline Moderate Growth & & & & & & \\
\hline National Bank of Abu Dhabi & 18,258 & 44 & $54 \%$ & $70 \%$ & $67.1 \%$ & $96 \%$ \\
\hline Union National Bank & 11,557 & 61 & $39 \%$ & $81 \%$ & $26.9 \%$ & $104 \%$ \\
\hline Mashreqbank & 11,390 & 4 & $39 \%$ & $62 \%$ & $31.9 \%$ & $80 \%$ \\
\hline Commercial Bank of Dubai & 7,312 & 9 & $28 \%$ & $52 \%$ & $41.4 \%$ & $96 \%$ \\
\hline Slow Growth & & & & & & \\
\hline Abu Dhabi Commercial Bank & 15,638 & 51 & $23 \%$ & $39 \%$ & $30.2 \%$ & $99 \%$ \\
\hline National Bank of Dubai & 15,648 & 95 & $13 \%$ & $117 \%$ & $11 \%$ & $56 \%$ \\
\hline Islamic & & & & & & \\
\hline Dubai Islamic Bank & 9,520 & 238 & $83 \%$ & $84 \%$ & $85.0 \%$ & $63 \%$ \\
\hline Abu Dhabi Islamic Bank & 4,075 & 146 & $77 \%$ & $209 \%$ & $96.3 \%$ & $81 \%$ \\
\hline
\end{tabular}

Sources: Central Bank of UAE, 2005; Financial Statements of Respective Banks, and EFG-Hermes

UAE banks have witnessed a gradual increase in their total asset / liability figures which increased from AED 192,532 million in 1996 to AED 334,743 million in mid 2003. Foreign assets to total assets were roughly one-third throughout the selected period. At the same time, foreign liability to total liability ratios reduced to $8.7 \%$ in June 2003 from $22.7 \%$ in 1998. Selected macro data of the UAE banking industry is summarized in Table 5.

Another interesting observation is that UAE residents have dominated the bank deposit and credit market. At the same time, the non-residents share of the deposits and credit market is increasing at a higher rate than the residents' market share. The fragmentation of the banking market is evident by the fact that the total number of domestic banks and branches had increased from 250 (in 1996) to 355 (in June 2003). In some UAE emirates, domestic banks are limited in their number of branches. Only Meshreq bank has branches in all seven emirates. Foreign banks and their branches have increased from 110 (in 1996) to 112 (in June 2003). The modest increase of foreign banks branches is due to the fact that no foreign banking license has been issued for over a decade, and foreign banks were limited to only eight branches in the country, until 2003.

The banking sector is a major employer in the UAE, although most of the employees are expatriates. Emiritization laws have forced domestic and foreign banks to increase their employment of UAE nationals. In 1996, total number of banking employees was only 11, 688, but this number increased to 16, 408 by June 2003. Primarily, this increase is due to the new branches of the domestic banks. Expatriate still dominate the banking sector employment numbers. (Table 5)

\section{Globalization Of Banking Sector}

The UAE has joined the World Trade Organization (WTO) and the country has aspirations to attract global capital and banks to their soil. As a result of the UAE government's WTO membership and global market oriented attitude, the country's banking sector will soon be completely open to foreign banks.

The most interesting development of UAE's banking sector is the creation of the Dubai International Financial Corporation (DIFC). DIFC is based on the offshore model; thus it does not control or restrict financial institutions. Foreign banks can enjoy $100 \%$ ownership with no restrictions on capital repatriation and a zero tax rate. DIFC is a financial free zone and a first step toward the complete liberalization of the UAE banking sector. (www.difc.com, 2006). The DIFC has licensed thirteen wholesale investment banks, including Credit Suisse, First Boston, Julius Baer, Merrill Lynch, Standard Chartered, Ansbacher Holdings, Franklin Templeton, Mellon Global Investment and Invesco. Another related development is the creation of the Dubai International Financial Exchange 
(DIFX) which will offer settlement and clearing facilities. Notable foreign banks including Deutsche Bank, SAMBA Group, Citigroup and Barclays Bank have expressed interest in entering the UAE market. One of the objectives is to bring back about two trillion dollars worth of Arab capital from foreign and offshore banking sectors. GCC competitors to the DIFC are the newly created Qatar Financial Center (QFC) and Bahrain Financial Harbor (BFH). (Siddiqi, 2005) Despite this competition, the Dubai International Financial Centre (DIFC) is going to play a major role in attracting foreign banks to the UAE after offering them a completely free market environment with virtually no UAE government interference. (www.difc.ae)

Table 5

Macro Data For Domestic \& Foreign Banks In UAE

\begin{tabular}{|c|c|c|c|c|}
\hline & 2000 & 2001 & 2002 & 2003 (June) \\
\hline \multicolumn{5}{|l|}{ Banks 1* } \\
\hline Total Assets/Liabilities & 277,101 & 299,669 & 333,235 & 334,743 \\
\hline Foreign Assets & 91,457 & 99,409 & 112,417 & 102,416 \\
\hline Foreign Assets to Total Assets (\%) & 33.0 & 33.2 & 33.7 & 30.6 \\
\hline Foreign Liabilities & 26,584 & 30,677 & 29,932 & 29,050 \\
\hline Foreign Liabilities to Total Liabilities (\%) & 9.6 & 10.2 & 9.0 & 8.7 \\
\hline Deposits 2* & 170,034 & 182,893 & 209,647 & 213,268 \\
\hline Residents 2 & 161,805 & 172,848 & 198,244 & 202,261 \\
\hline Non-Residents & 8,229 & 10,045 & 11,403 & 11,007 \\
\hline Bank Credit(Net) 3* & 124,915 & 132,484 & 157,881 & 169,548 \\
\hline Residents & 109,156 & 115,416 & 133,723 & 145,030 \\
\hline Non-Residents & 15,759 & 17,068 & 24,088 & 24,518 \\
\hline Total Number of Domestic Banks \& Branches 4 & 311 & 324 & 345 & 355 \\
\hline Head Offices & 20 & 20 & 21 & 21 \\
\hline Branches & 291 & 304 & 324 & 344 \\
\hline Total Number of Foreign Banks \& Branches 5 & 109 & 109 & 112 & 112 \\
\hline Head Offices & 26 & 26 & 26 & 25 \\
\hline Branches & 83 & 83 & 86 & 87 \\
\hline Number of Workers in Banks (U.A.E.) 6 & 14,621 & 15,191 & 16,080 & 16,408 \\
\hline
\end{tabular}

Source: Central Bank of UAE, 2004. (*) Including deposits of UAE residents booked in overseas branches (including offshore). (1) Including the restricted license bank until March 2003. (2) Not including inter-bank deposits. (3) Not including loans to banks, also provisions from 1999. (4) Including pay offices. (5) Including a pay office. (6) Excluding non banking staff.

The UAE has also decided to adopt Basel II international banking protocol to improve the overall performance of its banking system. The implementation stages of Basel II include legislation, bank readiness and adaptation of the standards by December 2006. (Editors, 2005) Some of the benefits of the Basel II standards to UAE are as follows:

- $\quad$ Creation of powerful risk management departments in the banks.

- $\quad$ Transparent reporting of the banks' financial data.

- $\quad$ Stability of the financial system.

- $\quad$ Detailed registration of risk types and range of risks.

- $\quad$ Differentiated considerations of the level of business risks.

UAE banks are represented in the major financial centers of the world. The five largest domestic banks operate 48 offices in 16 countries. The offices consist of branches, representative offices, restricted banking branches, offshore banking units and subsidiaries. Despite strong regional political affiliations with other Gulf countries, the UAE banks' presence in the GCC countries is limited to a branch in each Qatar and Oman and two overseas banking units in Bahrain. The GCC country's laws restricting intra-region banking may change in the future, as GCC countries have agreed to open up their markets to banks from member states. For instance, GCC members were allowed to open 
a branch in Kuwait in 2003. On the negative side, Asia, which accounts for around $40 \%$ of foreign trade, is poorly represented by UAE banks.

WTO membership is going to force the UAE government to completely open up its banking sector. Most of the UAE banks are small and still lack sophisticated bank management teams. At present, the domestic banks get preferential treatment from the UAE government and a few banks are partially owned by the government or government ministers. UAE banks must modernize their operation; otherwise most of the domestic banks may not be able to survive global competition if the market is opened today.

Another obstacle to the local banks is the weak Moody's financial strength rating of the UAE banks. Moody's International rates only four UAE based banks. (Table 6) The financial strength rating of these banks is from $\mathrm{C}$ to D-. This rating is well below the reputed international banks' rating. The long term debt rating is either "A" or not available, while the top rating can be Aaa or Aa. In this context, long term debt rating is in an acceptable range. Similarly, the long term bank deposit rating is satisfactory, but failed to get Aaaa or Aa rating. If the well known and bigger UAE banks have barely met the international banking standards, small domestic banks may be well below these standards. In part, the poor ratings can be explained by the political instability of the region and the lack of transparency in the financial dealings of UAE banks.

Small size, increased international competition, and perhaps lower financial ratings may encourage domestic bank consolidation. Domestic banks may either merge with other domestic banks or establish partnerships with international banks from the neighboring Arab and GCC countries, or from Europe and North America.

Table 6

Moody's Financial Rating Of Big UAE Banks

\begin{tabular}{|l|c|c|c|c|c|c|}
\hline \multicolumn{1}{|c|}{ Bank Name } & Outlook & $\begin{array}{c}\text { LT. Bank } \\
\text { Deposit }\end{array}$ & $\begin{array}{c}\text { Financial } \\
\text { Strength }\end{array}$ & $\begin{array}{c}\text { LT. Debts } \\
\text { Senior }\end{array}$ & $\begin{array}{c}\text { LT. Debt } \\
\text { Subordinate }\end{array}$ & Short Term \\
\hline Abu Dhabi Commercial Bank & POS(m) & A1 & D- & - & - & P1 \\
\hline Emirates Bank Int'1 & STA & A1 & C- & A1 & A2 & P1 \\
\hline Mashreq Bank & STA & A2 & C- & A2 & A3 & P1 \\
\hline NB of Abu Dhabi & STA & A1 & C & - & - & P1 \\
\hline
\end{tabular}

Source: Moody's International, 2005 (www.moodys.com)

\section{Comparison Of UAE Banking Sector With GCC Banking Sector}

Utilizing the Gulf Cooperation Council (GCC) banking data, the UAE banking sector is compared with the other five GCC members' banks. (Siddiqi, 2005) The results are summarized in Table 7.The UAE banking sector is somewhat comparable with other five counties. UAE equity to gross loans ratio (18.1\%) is the lowest among all countries which put UAE banks to at higher risk should there be dramatic increase in non-performing loans. Qatar and Bahrain based banks have much higher equity to gross loans ratio. Due to competitive and fragmented banking industry, UAE banks are generally less profitable compare to other five countries, as UAE ranked forth based on return on average equity and return on average assets rations. The efficiency ratios of the UAE banks are batter then most of the GCC member countries. UAE banks' cost to operating income ratio is only 35.6 percent which suggest a lower cost operation in UAE banks. Liquidity ratios of the UAE banks are in the middle of the all GCC members' ratios. The UAE banks have maintained good quality assets, which are evident by very low non-performing loans / gross loans ratio (2.7\%). Only Saudi Arabia has slightly low ratio, while other four country's ratios are much higher so their assets quality is poor compare to UAE banks. This is an evidence of efficient and professional management of UAE banks and it had made UAE banks financially sound compare with the banks in other GCC countries. 
Table 7

Aggregate Data For GCC Banking Sector, (2004)

\begin{tabular}{|l|c|c|c|c|c|c|}
\hline & Kuwait & $\begin{array}{c}\text { Saudi } \\
\text { Arabia }\end{array}$ & Oman & Qatar & UAE & Bahrain \\
\hline Capitalization (\%) & & & & & & \\
\hline Capital Adequacy Ratio & 16.5 & 16.2 & 25.2 & 25.9 & 16.4 & 24.8 \\
\hline Equity to Total Assets & 13.0 & 10.5 & 15.0 & 16.5 & 12.0 & 13.7 \\
\hline Equity to Gross Loans & 22.9 & 19.5 & 18.2 & 31.5 & 18.1 & 24.9 \\
\hline Profitability (\%) & & & & & & \\
\hline Return on Average Equity & 20.6 & 26.4 & 9.3 & 20.4 & 17.4 & 13.6 \\
\hline Return on Average Assets & 2.4 & 2.7 & 1.2 & 2.9 & 2.4 & 1.7 \\
\hline Net Spread & 2.6 & 3.5 & 3.9 & 3.4 & 2.7 & 2.0 \\
\hline Dividend Payout Ratio & 62.3 & 55.8 & 57.0 & 52.1 & 41.1 & 70.3 \\
\hline Efficiency (\%) & & & & & & \\
\hline Cost to Operating Income & 29.3 & 38.6 & 59.4 & 34.7 & 35.6 & 50.2 \\
\hline Staff Expenses/Operating Income & 17.2 & 21.7 & 24.2 & 16.2 & 20.8 & 27.9 \\
\hline Liquidity (\%) & & & & & & \\
\hline Net Loans/Customer Deposits & 83.4 & 63.0 & 105.0 & 65.0 & 90.1 & 92.7 \\
\hline Customer Deposit/Total Deposit & 95.4 & 87.2 & 89.2 & 74.6 & 88.4 & 79.8 \\
\hline Asset Quality & & & & & & \\
\hline Non-performing Loans (\$ mil) & 1,342 & 1,709 & 1,234 & 675 & 1,443 & 539 \\
\hline NPLs / Gross Loans (\%) & 4.5 & 2.2 & 14.7 & 5.0 & 2.7 & 7.0 \\
\hline Provisions / NPLs (\%) & 121 & 177 & 90.0 & 83.7 & 107.7 & 82.4 \\
\hline
\end{tabular}

Source: Siddiqi (2005)

\section{SUMMARY AND FUTURE DIRECTIONS}

A total of 21 domestic and 25 foreign banks are operating in UAE, while another 36 foreign banks have opened representative offices. Despite these numbers, the UAE banking sector is dominated by the top five domestic banks that control about half of the loan and deposit share. As a result, most of the domestic and foreign banks are clinging to a very small market share. Only two foreign banks (HSCB, Standard Chartered) made it to the top-ten list of the banks operating in UAE, based on deposits and loans.

A detailed analysis of these banks, particularly domestic banks, reveals a high growth rate, a healthy spread over the deposit rate, and an absence of banking fraud during the 2001-2004 period. Central Bank of the UAE has played an important role in streamlining the banking operation and increasing consumer confidence. Furthermore, the DIFC has been a catalyst in attracting internationally reputed commercial banks and financial institutions. In comparison to the GCC banks, UAE banks have performed better than other country's banks. Only Kuwati banks have generally better performed than UAE banks.

The banking sector, however, is not free from problems. Major domestic banks have received low Moody's financial strength ratings. One problem facing the banking sector which contributed to these low scores is the lack of supervision in multiple ownership situations. For example, commercial banks do maintain the majority share in insurance and equity firms, and there is no formal mechanism to monitor possible anti-trust violations. The contradictions among the banking laws of all six emirates and the inconsistencies between the federal and each emirate's banking laws pose more problems for the country. Because of these contradictions, the country's courts can make conflicting judgments in some instances.

International Monetary Fund (IMF) has positive comments about the readiness of the UAE financial and banking sectors to be part of a global system. UAE banking industry is profitable and well guided by the Central Bank. In addition, the banking sector of the UAE is going to play a major role in further globalization of UAE economy. 


\section{REFERENCES}

1. Al-Tamimi, Hussain and Abdulla Al-Ameri, (2003) Analyzing Service Quality in UAE Islamic Banks, Journal of Financial Services Marketing, Vol.8, 2, PP: 119-132.

2. Central Bank of the United Arab Emirates, January 2006, http://www.cbuae.gov.ae/.

3. DeGregorio, Jose and Gudotti, Pablo E., Financial Development and Economic Growth, World Development, March 1995.23 (3), 433-48.

4. Dubai International Financial Centre (2006), www.DIFC.ae.

5. Duncan, E. and Elliott, G. (2002) Customer Service Quality and Financial Performance Among Australian Retail Financial Institutions, Journal of Financial Services Marketing, Vol.7, 1, PP: 25-41.

6. $\quad$ Editors (2005) Basel III Standards, Khaleej Times, January 3, 2005.

7. EFG Hermes, http://www.efg-hermes.com/.

8. El-Kuwaiz, Abdullah (1995) Banking in GCC: Challenges and Opportunities. Arab Bank and Finance Directory, 1994-95, 372-374.

9. $\quad$ Financial Reports of the Sixteen Commercial Banks, 2003-2004.

10. Goldsmith, Raymond W (1969) Financial Structure and Development. New Haven, CT, Yale University Press, 1969.

11. King, Robert G. and Levine, Ross (1993) Finance and Growth: Schumpeter Might Be Right, Quarterly Journal of Economics, August 1993a, 108 (3), 717-38.

12. Mahasneh, Quhafah (2004) Strategic Orientation of Banking and Finance Managers in United Arab Emirates, Journal of American Academy of Business, March 2004, Vol. 4, 1/2, PP. 136-142.

13. Mazhar M. Islam (2003) Development and Performance of Domestic and Foreign Banks in GCC Countries, Managerial Finance, Vol. 29, 2/3, PP: 42-73.

14. Rao, Ananth (2002) Estimation of Efficiency, Scale \& Scope and Productivity Measures of UAE Banks, European Conference of Financial Management Association, Copenhagen, June 2002.

15. Siddiqi, Moin (2005) Banking Report: Strong Regional Economy Sees Banking Profits Soar, The Middle East, October 2005, PP: 34-43.

16. United Arab Emirates: Financial System Stability assessment, including Reports on the Observance of Standards and Codes on the following topics: Monetary and Financial Policy Transparency, Banking Supervision and Payment Systems, IMF Country Report No. 03/20, January 2003, International Monetary Fund, Washington, D.C.

\section{APPENDIX 1}

\begin{tabular}{|c|c|}
\hline Domestic Banks Operating in UAE & Foreign Banks Operating in UAE \\
\hline 1. $\quad$ Abu Dhabi Islamic Bank (ADIB) & 1. $\quad$ Al Ahli Bank of Kuwait K.S.C. \\
\hline 2. Abu Dhabi Commercial Bank (ADCB) & 2. ABN-Amro Bank N.V. \\
\hline 3. Arab Bank for Invest. \& Foreign Trade & 3. Arab African International Bank \\
\hline 4. Bank of Sharjah (BOS) & 4. Arab Bank plc. \\
\hline 5. $\quad$ Commercial Bank International (CBI) & 5. Bank of Baroda \\
\hline 6. Commercial Bank of Dubai (CBD) & 6. Bank Saderat Iran \\
\hline 7. Dubai Bank & 7. Bank Melli Iran \\
\hline 8. $\quad$ Dubai Islamic Bank (DIB) & 8. Banque Banorabe \\
\hline 9. $\quad$ Emirates Bank International (EBI) & 9. Barclays Bank Plc. \\
\hline 10. First Gulf Bank (FGB) & 10. Banque du Caire \\
\hline 11. Invest Bank & 11. Credit Agricole Indosuez \\
\hline 12. Mashreq Bank (MASHREQ) & 12. BLC (France) S.A. \\
\hline 13. Middle East Bank & 13. BNP Paribas \\
\hline 14. National Bank of Abu Dhabi (NBAD) & 14. HSBC Bank Middle East (HSBC) \\
\hline 15. National Bank of Dubai (NBD) & 15. Citibank N.A. \\
\hline 16. National Bank of Fujairah & 16. El-Nilein Bank \\
\hline 17. National Bank of Ras Al Khaimah & 17. Habib Bank A.G.Zurich \\
\hline 18. National Bank of Sharjah (NBOS) & 18. Habib Bank Limited \\
\hline
\end{tabular}




\begin{tabular}{|l|l|}
\hline 19. National Bank of Umm Al Qaiwain & 19. Janata Bank \\
\hline 20. Union National Bank (UNB) & 20. Lloyds TSB Bank Plc \\
\hline 21. United Arab Bank & 21. National Bank of Bahrain \\
\hline & 22. National Bank of Oman S.A.O.G. \\
\hline & 23. Rafidain Bank \\
\hline & 24. Standard Chartered Bank (Stan Chart) \\
\hline
\end{tabular}

APPENDIX 2

\begin{tabular}{|c|c|}
\hline \multicolumn{2}{|c|}{ Representative Offices Of The Foreign Banks } \\
\hline 1. American Express Bank Ltd. & 19. Kotak Mahindra International Ltd. \\
\hline 2. Bank Brussels Lambert & 20. Kuwait Interests for Financial Investments (KSC) \\
\hline 3. $\quad$ Bank Muscat (S.A.O.G) & 21. Man Investment Ltd. \\
\hline 4. Bank of America - National Association & 22. Merrill Lynch Bank (Suisse) S.A \\
\hline 5. Bank of Bahrain and Kuwait (B.S.C) & 23. Natexis Banque - Pupulaires \\
\hline 6. $\quad$ Bank of Beirut SAL & 24. Nationwide International Ltd. \\
\hline 7. $\quad$ ICICI Bank Ltd. & 25. Philippine National Bank \\
\hline 8. $\quad$ Citi Group Global Markets & 26. Royal Bank of Canada \\
\hline 9. $\quad$ Clearstream Banking S.A. & 27. Societe Generale Bank \\
\hline 10. Coutts \& Co. & 28. Standard Bank London Ltd \\
\hline 11. Credit Suisse & 29. State Street Bank and Trust Company \\
\hline 12. Deutsche Bank AG & 30. Towry Law (Asia) HK Ltd \\
\hline 13. Dresdner Bank A.G. & 31. UBS A.G. \\
\hline 14. Fidelity Investments International & 32. Union Bancaire Privee (CBI-TDB) \\
\hline 15. HDFC Bank Ltd. & 33. Union de Banques Arabes et Francaises (UBAF) \\
\hline 16. HSBC Bank International Ltd. & 34. Unit Trust Of India \\
\hline 17. Indusin Bank Ltd. & 35. Wachovia Bank National Association \\
\hline 18. Korea Exchange Bank & 36. West LB A.G. \\
\hline
\end{tabular}




\section{NOTES}

